\title{
Three new species of Neocamarosporium isolated from saline environments: $N$. aestuarinum sp. nov., $N$. endophyticum sp. nov. and $N$. halimiones sp. nov.
}

\author{
Gonçalves MFM, Aleixo A, Vicente TFL, Esteves AC* and Alves A \\ Departamento de Biologia, CESAM, Universidade de Aveiro, 3810-193 Aveiro, Portugal \\ *current address: Universidade Católica Portuguesa, Institute of Health Sciences (ICS), Viseu, Portugal
}

Gonçalves MFM, Aleixo A, Vicente TFL, Esteves AC, Alves A 2019 - Three new species of Neocamarosporium isolated from saline environments: $N$. aestuarinum sp. nov., $N$. endophyticum sp. nov. and $N$. halimiones sp. nov. Mycosphere 10(1), 608-621, Doi 10.5943/mycosphere/10/1/11

\begin{abstract}
Neocamarosporium species are typically halotolerant, being commonly found in saline environments like saline water, hypersaline soils and especially in association with halophytes. Several isolates were obtained from saline water, dead leaves of the seaweed Zostera noltii and live tissues of the halophyte Halimione portulacoides. Phylogenetic analysis based on ITS sequence data placed these isolates into three clades within the genus Neocamarosporium distinct from the currently known species. Isolates from each clade showed clear differences in conidial morphology. Three new species $N$. aestuarinum sp. nov., $N$. endophyticum sp. nov. and $N$. halimiones sp. nov. are described and illustrated. Our results show that the salt marsh plant $H$. portulacoides harbours a high diversity of Neocamarosporium species.
\end{abstract}

Key words - Neocamarosporiaceae - Endophyte - Halophyte - Seagrass - Salt marsh

\section{Introduction}

Camarosporium-like taxa has been shown to be polyphyletic, thus resulting in the introduction of several novel genera, namely Neocamarosporium (Crous et al. 2014a), Paracamarosporium and Pseudocamarosporium (Wijayawardene et al. 2014), Xenocamarosporium (Crous et al. 2015), Magnicamarosporium (Tanaka et al. 2015), Phragmocamarosporium (Wijayawardene et al. 2015), Didymellocamarosporium and Melanocamarosporium (Wijayawardene et al. 2016).

Neocamarasporium was introduced by Crous et al. (2014a) with N. goegapense Crous \& M.J. Wingf as the type species that was first isolated from dying leaves of Mesembryanthemum sp. in South Africa. Although morphologically very similar to Camarosporium (e.g. pycnidial conidiomata, conidiophores reduced to conidiogenous hyaline cells, proliferating percurrently and brown, smooth muriform conidia), it is phylogenetically distinguishable (Crous et al. 2014a, b, Wijayawardene et al. 2014, 2016, Wanasinghe et al. 2017, Ariyawansa et al. 2018). Currently, the genus comprises 15 species listed in the Index Fungorum (2019) and Mycobank databases. Although initially treated as a genus in the family Pleosporaceae, multi-gene phylogenies supported a new family, Neocamarosporiaceae Wanas., Wijayaw., Crous \& K.D. Hyde in Pleosporales (Wanasinghe et al. 2017). 
Most species of Neocamarosporium have been found in association with halophytes (salttolerant plants) in marine or estuarine habitats (Papizadeh et al. 2017). Some examples are $N$. salicorniicola Dayarathne, E.B.G. Jones \& K.D. Hyde found on dead stems of Salicornia sp. in Thailand, N. salsolae Wanas., Gafforov \& K.D. Hyde on dead stems of Salsola sp. in Uzbekistan, $N$. obiones Wanas. \& K.D. Hyde on stems of Halimione portulacoides in Netherlands, and $N$. calvescens in Atriplex hastata in Germany (de Gruyter et al. 2013, Ariyawansa et al. 2015, Wijayawardene et al. 2017a). In addition, $N$. chichastianum was also found in saline soil of Lake Urima in Iran. Papizadeh et al. (2017) introduced three novel Neocamarosporium species: $N$. jorjanensis Papizadeh, Wijayaw, Amoozegar, Shahzadeh Fazeli, \& K.D. Hyde, N. persepolisi Papizadeh, Wijayaw, Amoozegar, Shahzadeh Fazeli, \& K.D. Hyde and N. solicola Papizadeh, Wijayaw, Amoozegar, Shahzadeh Fazeli \& K.D. Hyde, all of them have also been isolated from saline environments in Iran.

Saline environments, including salt marshes, mangroves, saline soils and water cover a wide area of the planet and harbour a considerable fungal diversity with many new species described recently (Hyde \& Jones 1998, Poon \& Hyde 1998, Hyde \& Pointing 2000, Sarma \& Hyde 2001, Jones et al. 2015, Wijayawardene et al. 2017a, 2017b, Devadatha et al 2018a, 2018b). These environments also receive fungi from terrestrial sources that here find new niches for evolution (Azevedo et al. 2011). Despite this, the biology and ecology of fungi in these habitats are still poorly studied (Kis-Papo et al. 2001, 2003, Gunde-Cimerman et al. 2004, Butinar et al. 2005a, b).

During an extensive survey of the fungal diversity in marine and estuarine environments in Portugal, we have obtained a number of camarosporium-like isolates. The aim of this study was to characterise these isolates based on morphological, cultural and DNA sequence analyses.

\section{Materials \& Methods}

\section{Collection and Isolation}

Water samples were collected from the sea at Vila Real de Santo António, near to the mouth

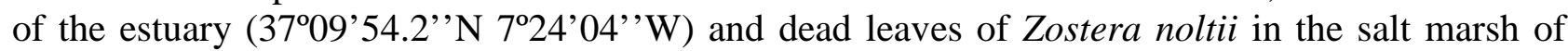
Ria de Aveiro (40'39'33.3'’ N 843'27.4'’W) in Portugal. Samples were placed in sterile plastic containers and maintained at $4{ }^{\circ} \mathrm{C}$ until fungal isolation. Water samples were vacuum filtered with sterile $0.22 \mu \mathrm{m}$ cellulose membranes (Lifesciences). Then, the membranes were vigorously washed in $10 \mathrm{~mL}$ of autoclaved filtered saline water (AFSW). Aliquots of $100 \mu \mathrm{l}$ from each water sample were spread onto Potato Dextrose Agar (PDA) containing 3 \% sea salts (Sigma-Aldrich). Z. noltii samples were washed with AFSW, cut into small pieces and placed on PDA enriched with $3 \%$ sea salts. Streptomycin and tetracycline, at final concentrations of $100 \mathrm{mg} / \mathrm{L}$, were added to PDA medium to inhibit the growth of bacteria. Five replicates of agar plates were used for each sample. The plates were incubated at $25^{\circ} \mathrm{C}$ and examined daily to observe the growth of fungal hyphae. Distinct fungal colonies were then transferred to new agar plates for further isolation and purification.

Endophytic isolates from the halophyte Halimione portulacoides were obtained in a previous study (Aleixo et al. unpublished). Briefly, $H$. portulacoides samples were collected from three distinct sites in Ria de Aveiro and the roots, stems and leaves tissues were used for isolation. After the surface sterilization, all tissues were cut into small pieces and placed on PDA and incubated at $25{ }^{\circ} \mathrm{C}$ for the growth of fungal colonies.

\section{DNA isolation, amplification and analyses}

Genomic DNA was extracted from fresh mycelium of cultures growing on PDA according to Möller et al. (1992). The primers ITS1 and ITS4 (White et al. 1990) were used for amplification and sequencing of the ITS region of the ribosomal DNA as described by Alves et al. (2004). The amplified PCR fragments were purified with the NZYGelpure kit (NZYTech, Portugal) before sequencing at GATC Biotech (Cologne, Germany). The nucleotide sequences were analysed with FinchTV v.1.4.0 (Geospiza Inc. www.geospiza.com/finchtv). A BLASTn search against GenBank 
database using the ITS sequence was carried out to determine the closest matching sequences, which were added to the sequence alignment. Sequences were aligned with ClustalX v. 2.1 (Thompson et al. 1997), using the following parameters: pairwise alignment parameters (gap opening $=10$, gap extension $=0.1$ ) and multiple alignment parameters (gap opening $=10$, gap extension $=0.2$, transition weight $=0.5$, delay divergent sequences $=25 \%$ ). Alignments were checked and edited with BioEdit Alignment Editor v.7.2.5 (Hall 1999). Phylogenetic analyses were done with MEGA7 v.7.0 (Kumar et al. 2016). All gaps were included in the analyses. MEGA7 v.7.0 was also used to determine the best substitution model to be used to build the Maximum Likelihood (ML) tree. ML analysis was performed on a Neighbour-Joining (NJ) starting tree automatically generated by the software. Nearest-Neighbour-Interchange (NNI) was used as the heuristic method for tree inference with 1,000 bootstrap replicates. The sequences generated in this study were deposited in GenBank and taxonomic novelties in Mycobank (www.mycobank.org) and Faces of Fungi (http://www.facesoffungi.org). Alignment and tree were deposited in TreeBase (S24085).

\section{Morphology and growth studies}

The morphological observations were performed using a SMZ1500 stereoscopic microscope and a Nikon Eclipse 80i microscope (Nikon, Japan). Measurements and photographs of the fungal structures, mounted in $100 \%$ lactic acid, were taken with a Nikon DSRi1 camera (Nikon, Japan) and the NIS-Elements D program (Nikon, Japan). Colony characters and pigment production were registered after 2 weeks of growth on PDA, Malt Extract Agar (MEA) and Oatmeal Agar (OA) incubated at $25^{\circ} \mathrm{C}$. Colony colours (surface and reverse) were assessed according to the colour charts of Rayner (1970). Morphological descriptions were based on cultures sporulating on PDA enriched with $3 \%$ sea salts, after 2 weeks incubated at $25^{\circ} \mathrm{C}$.

The reaction of the isolates to a gradient of temperatures was observed. A 5-mm diameter plug was taken from the margin of an actively growing colony (14-day-old) and placed in the centre of PDA, MEA and OA plates. Three replicate plates per isolate were incubated at 10, 15, 20, 25, 30 and $35^{\circ} \mathrm{C}$ in the darkness and the colony diameter was measured after 7 and 14 days.

To evaluate the requirement of sea salts for growth, each species was cultured on PDA with and without the addition of $3 \%$ sea salts. Three replicate plates per isolate were incubated at $25{ }^{\circ} \mathrm{C}$ for 14 days in the dark. After incubation, the diameter of the colonies was measured and compared.

\section{Results}

\section{Phenotypic characterisation}

On the basis of conidial morphology, the isolates studied were divided into three groups: 1) isolates with aseptate golden-brown conidia; 2) isolates with 1-septate golden-brown conidia and 3) isolates with muriform septate golden-brown conidia.

For all isolates and all culture media tested, the minimum, maximum and optimal growth temperatures were 10,30 and $25^{\circ} \mathrm{C}$, respectively, with the exception of OA where the maximum growth temperature was $35{ }^{\circ} \mathrm{C}$. For all isolates tested no differences were observed in terms of colony diameter when grown in PDA with and without the addition of $3 \%$ sea salts, thus showing that sea salts are not required for growth of the isolates.

\section{Phylogeny}

BLASTn searches against the NCBI GenBank nucleotide database using the ITS sequences of the isolates retrieved various hits, of which those with the highest sequence similarity belonged to members of the genus Neocamarosporium. Thus, the sequences generated in this study and sequences from Neocamarosporium species deposited in GenBank were included in a phylogenetic analysis (Table 1). The alignment of the ITS region contained 39 sequences (including the outgroup), and there was a total of 598 positions in the final dataset. The phylogenetic tree generated by ML analysis confirmed that the isolates studied fall into the genus Neocamarosporium 
(Neocamarosporiaceae, Pleosporales). Pyrenochaetopsis tabarestanensis (IBRC-M 30051) was used as outgroup.

Table 1 List of isolates used in this study.

\begin{tabular}{|c|c|c|c|c|}
\hline Species & Strain & Host/Substrate & Country & ITS \\
\hline Alternaria eureka & CBS 193.86* & Medicago rugosa & Australia & MH861937 \\
\hline Comoclathris spartii & MFLUCC 13-0214* & Spartium junceum & Italy & KM577159 \\
\hline \multirow{2}{*}{ Foliophoma fallens } & CBS 284.70 & Nerium oleander & Italy & MH859609 \\
\hline & CBS 161.78 & Olea europaea & New Zealand & KY929147 \\
\hline Libertasomyces quercus & CBS 134.97* & Quercus ilex & Spain & KY929152 \\
\hline \multirow{2}{*}{$\begin{array}{l}\text { Neocamarosporium } \\
\text { aestuarinum }\end{array}$} & MUM 18.55/CMG 4* & Saline water & Portugal & MH397366 \\
\hline & CAA 803 & Halimione portulacoides & Portugal & MK139931 \\
\hline \multirow{5}{*}{$\begin{array}{l}\text { Neocamarosporium } \\
\text { betae }\end{array}$} & CBS 109410 & Beta vulgaris & - & KY940790 \\
\hline & CBS 112.85 & Beta vulgaris & Denmark & KY940782 \\
\hline & CBS 111.85 & Beta vulgaris & Denmark & KY940781 \\
\hline & CBS 236.28 & Solanum tuberosum & Netherlands & KY940746 \\
\hline & CBS 523.66 & Beta vulgaris & Netherlands & FJ426981 \\
\hline \multirow{3}{*}{$\begin{array}{l}\text { Neocamarosporium } \\
\text { calvescens }\end{array}$} & CBS 246.79 & Atriplex hastata & Germany & KY940774 \\
\hline & CBS 343.78 & Atriplex hastata & Netherlands & KY940773 \\
\hline & CBS 215.57 & $-\quad 1$ & UK & KY940760 \\
\hline $\begin{array}{l}\text { Neocamarosporium } \\
\text { chersinae }\end{array}$ & CPC 27298* & $\begin{array}{l}\text { Dead angulate tortoise } \\
\text { shell }\end{array}$ & South Africa & NR_154261 \\
\hline $\begin{array}{l}\text { Neocamarosporium } \\
\text { chichastianum }\end{array}$ & CBS 137502/IBRC-M 30126* & $\begin{array}{l}\text { Saline soil of Lake } \\
\text { Urima }\end{array}$ & Iran & KM670458 \\
\hline $\begin{array}{l}\text { Neocamarosporium } \\
\text { endophyticum }\end{array}$ & $\begin{array}{l}\text { MUM 18.56/CAA 808* } \\
\text { CAA } 809 \\
\text { CAA } 804 \\
\text { CMG } 10\end{array}$ & $\begin{array}{l}\text { Halimione portulacoides } \\
\text { Halimione portulacoides } \\
\text { Halimione portulacoides } \\
\text { Dead leaves of Zostera } \\
\text { noltii }\end{array}$ & $\begin{array}{l}\text { Portugal } \\
\text { Portugal } \\
\text { Portugal } \\
\text { Portugal }\end{array}$ & $\begin{array}{l}\text { MK139935 } \\
\text { MK139936 } \\
\text { MK139937 } \\
\text { MK492323 }\end{array}$ \\
\hline $\begin{array}{l}\text { Neocamarosporium } \\
\text { goegapense }\end{array}$ & CPC 23676/CBS 138008* & Mesembryanthemum sp. & South Africa & KJ869163 \\
\hline $\begin{array}{l}\text { Neocamarosporium } \\
\text { halimiones }\end{array}$ & $\begin{array}{l}\text { MUM 18.54/CAA 807* } \\
\text { CAA } 805 \\
\text { CAA } 806 \\
\end{array}$ & $\begin{array}{l}\text { Halimione portulacoides } \\
\text { Halimione portulacoides } \\
\text { Halimione portulacoides }\end{array}$ & $\begin{array}{l}\text { Portugal } \\
\text { Portugal } \\
\text { Portugal } \\
\end{array}$ & $\begin{array}{l}\text { MK139932 } \\
\text { MK139933 } \\
\text { MK139934 } \\
\end{array}$ \\
\hline $\begin{array}{l}\text { Neocamarosporium } \\
\text { jorjanensis }\end{array}$ & IBRC-M 30243* & Hypersaline soil & Iran & KX817213 \\
\hline Neocamarosporium korfii & MFLUCC 17-0745* & - & Russia & NR_154268 \\
\hline Neocamarosporium & MFLU 15-2989* & Lamiaceae sp. & Russia & NR_154269 \\
\hline lamiacearum & MFLUCC 17-0750 & - & Russia & MF434192 \\
\hline $\begin{array}{l}\text { Neocamarosporium } \\
\text { obiones }\end{array}$ & $\begin{array}{l}\text { CBS } 786.68 \\
\text { CBS } 432.77 \\
\end{array}$ & $\begin{array}{l}\text { Halimione portulacoides } \\
\text { Halimione portulacoides }\end{array}$ & $\begin{array}{l}\text { Netherlands } \\
\text { Netherlands }\end{array}$ & $\begin{array}{l}\text { GU230753 } \\
\text { GU230752 }\end{array}$ \\
\hline $\begin{array}{l}\text { Neocamarosporium } \\
\text { persepolisi }\end{array}$ & IBRC-M 30134* & Hypersaline soil & Iran & KX817215 \\
\hline $\begin{array}{l}\text { Neocamarosporium } \\
\text { phragmitis }\end{array}$ & MFLUCC 17-0756* & Phragmites australis & UK & MG844345 \\
\hline $\begin{array}{l}\text { Neocamarosporium } \\
\text { salicorniicola }\end{array}$ & MFLU 15-0957* & Salicornia sp. & Thailand & NR_154270 \\
\hline $\begin{array}{l}\text { Neocamarosporium } \\
\text { salsolae }\end{array}$ & MFLU 17-0192* & Salsola sp. & Uzbekistan & NR_154271 \\
\hline $\begin{array}{l}\text { Neocamarosporium } \\
\text { solicola }\end{array}$ & IBRC-M 30257* & Hypersaline soil & Iran & KX817217 \\
\hline Paradendryphiella salina & CBS 142.60* & Spartina stem & UK & MH857928 \\
\hline $\begin{array}{l}\text { Pyrenochaetopsis } \\
\text { tabarestanensis }\end{array}$ & IBRC-M 30051* & Rice farm & Iran & NR_155636 \\
\hline Stemphylium vesicarium & CBS 191.86* & Medicago sativa & India & MH861935 \\
\hline
\end{tabular}


CBS; MFLU: Herbarium of Mae Fah Luang University; IBRC: Iranian Biological Resource Center; MUM: Culture collection hosted at Center for Biological Engineering of University of Minho, Portugal. MFLUCC: Mae Fah Luang University Culture Collection, Chiang Rai, Thailand. Ex-type, ex-epitype, or isotype strains are marked with an asterisk. Sequences generated in this study are shown in bold.

In the ML ITS phylogenetic tree (Fig. 1) the isolates studied clustered into three distinct clades that received high bootstrap supports: clade 1 and 3 (99\%) and clade 2 (91\%). These three clades match exactly the same three groups previously defined on the basis of conidial morphology. Thus, these morphologically and phylogenetically distinct groups of isolates are deemed to represent three novel species of Neocamarosporium, which are described here in detail.

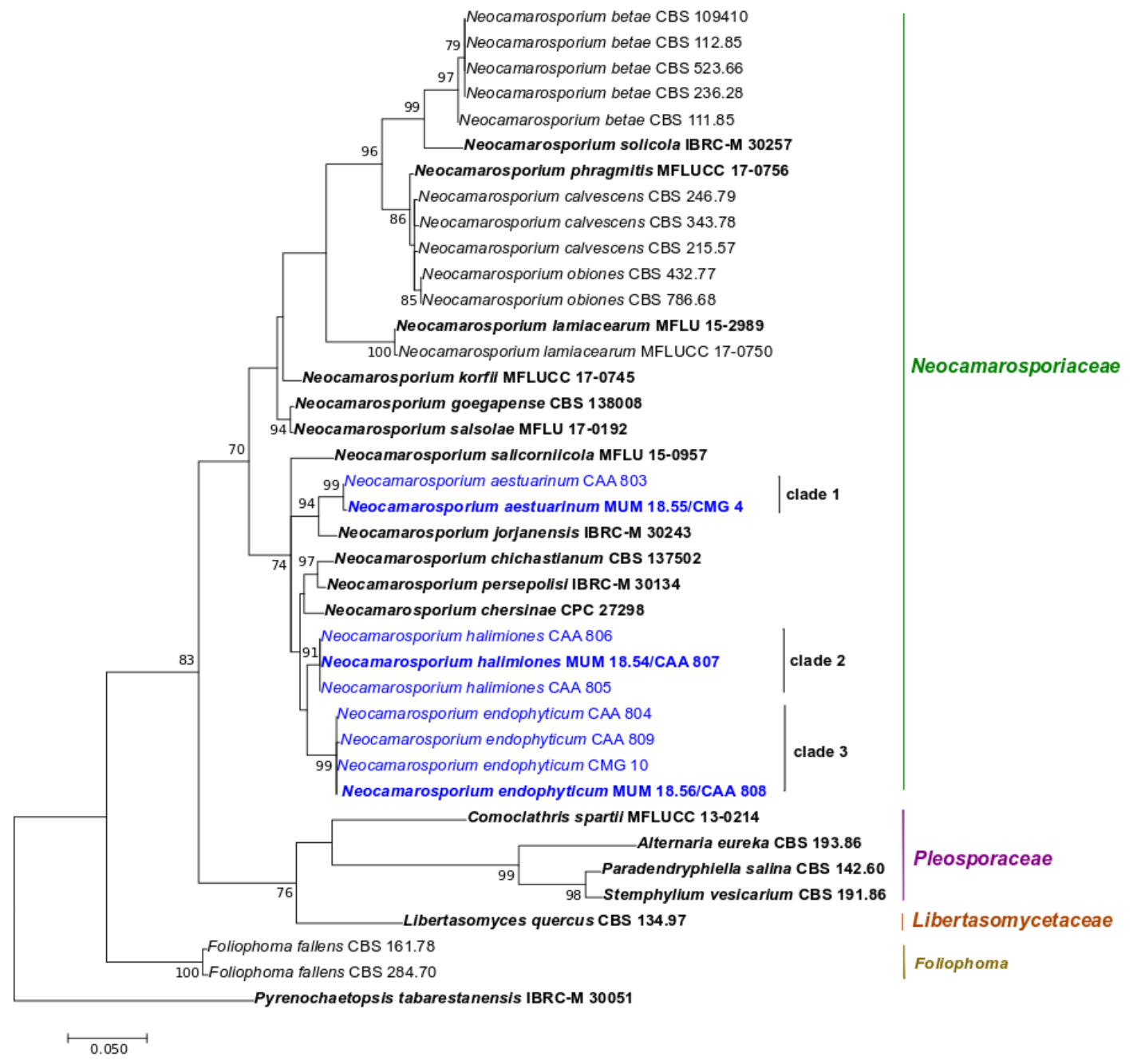

Figure 1 - Phylogenetic relationships of Neocamarosporium species based on ITS sequence data and inferred using the Maximum Likelihood method under the Kimura 2-parameter model. The tree is drawn to scale, with branch lengths measured in the number of substitutions per site and rooted to P. tabarestanensis (IBRC-M 30051). Bootstrap values (> 70\%) are shown at the nodes. Exholotype, ex-epitype, or ex-isotype strains are in bold and the isolates from the current study are in blue.

\section{Taxonomy}

Neocamarosporium aestuarinum M. Gonçalves \& A. Alves, sp. nov.

Fig. 2

Mycobank: MB829965; Facesoffungi number: FoF06133

Etymology - named for the environment it was first isolated from, namely an estuary.

Holotype - MUM-H 18.55 
Endophytic in marine habitats. Sexual morph: not observed. Asexual morph: coelomycetous. Conidiomata solitary, pycnidial, immersed to erumpent and globose. Paraphyses absent. Conidia (mean \pm S.D. $=10.7 \pm 2.5 \times 12.1 \pm 2.0 \mu \mathrm{m}, \mathrm{n}=50$ ), solitary, initially hyaline, aseptate, thickwalled, developing a central septum and becoming muriform when mature with shape variable from globose to obovoid to ellipsoid or subcylindrical or irregular, golden-brown, finely roughened.

Culture characteristics - Colonies smooth, with fluffy aerial mycelium, lighter in the centre getting a colour towards the periphery. On PDA surface, margin semi regular, blood colour, smoke grey near the centre; reverse blood colour. On MEA surface, margins flesh with little tuffs of aerial mycelium, dirty white near the centre; reverse light blood colour. On OA, olivaceous-black near the centre getting lighter towards the borders, with tuffs of dirty white mycelium. Colonies growing slower on PDA and MEA, reaching $20 \mathrm{~mm}$ in 14 days at $25{ }^{\circ} \mathrm{C}$, in darkness. On OA the colonies grew fast reaching $90 \mathrm{~mm}$ in the same time. At $35^{\circ} \mathrm{C}$, there was only growth on OA with $50 \mathrm{~mm}$ in 14 days.

Known distribution - Portugal.

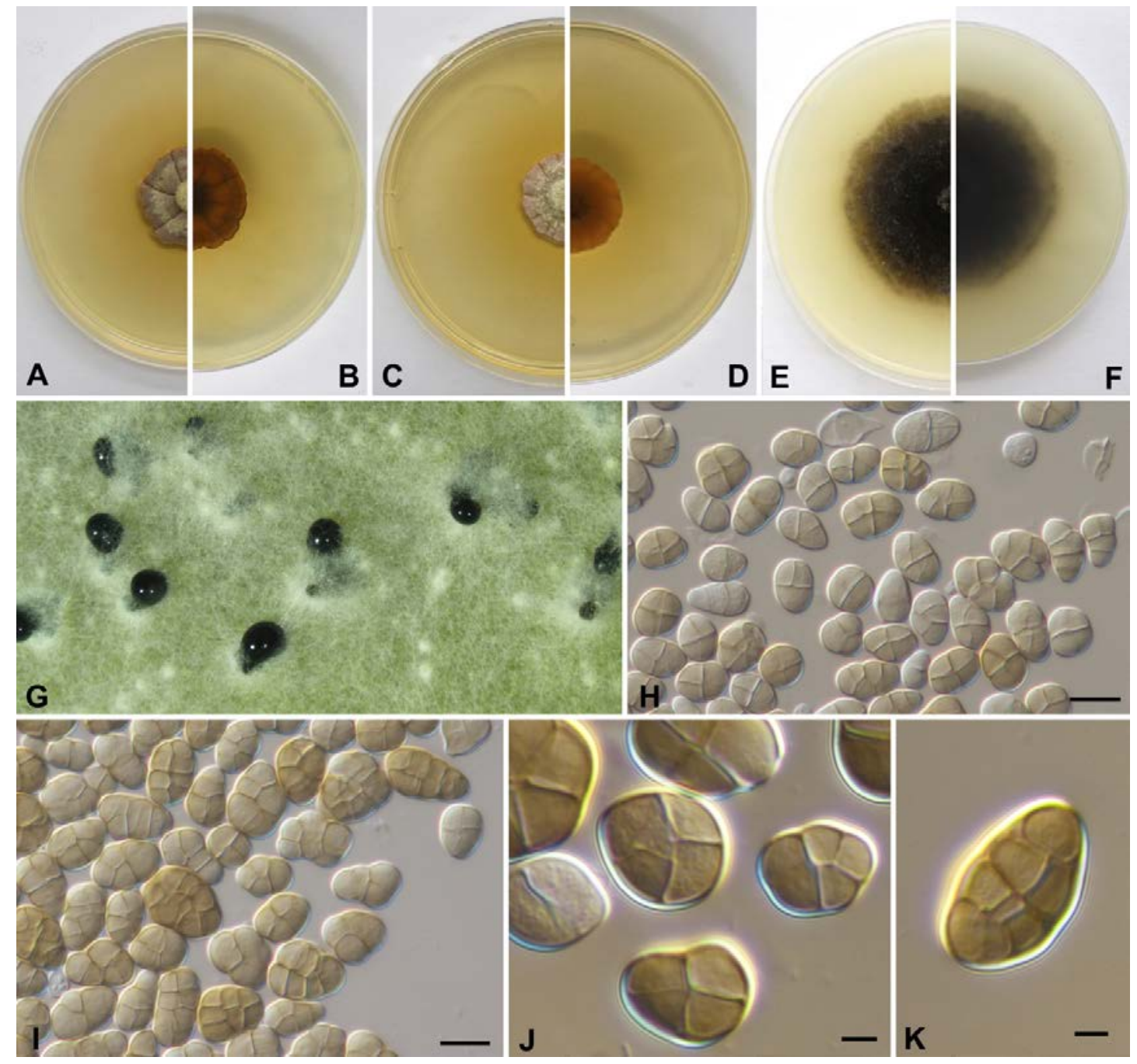

Figure 2 - Neocamarosporium aestuarinum (MUM 18.55). a-b Colony after 2 weeks at $25{ }^{\circ} \mathrm{C}$ on PDA (B reverse). c-d Colony after 2 weeks at $25^{\circ} \mathrm{C}$ on MEA (D reverse). e-f Colony after 2 weeks at $25^{\circ} \mathrm{C}$ on OA (F reverse). g Conidiomata developed on PDA. h-k Conidia. Scale bars: $\mathrm{h}-\mathrm{i}=10$ $\mu \mathrm{m}, \mathrm{j}-\mathrm{k}=2.5 \mu \mathrm{m}$.

Material examined - Portugal, Vila Real de Santo António, from sea water, October 2017, M. Gonçalves, (MUM-H 18.55 holotype), a dried culture sporulating, ex-holotype living culture, MUM 18.55 = CMG 4. 
Note - Neocamarosporium aestuarinum is phylogenetically closely related but distinct from $N$. jorjanensis (IBRC-M 30243). Although conidial dimensions of both species are similar in length, conidia of $N$. aestuarinum are more globose with a wider width than $N$. jorjanensis. Also, they differ in 23 nucleotide positions in ITS (Tables 2, 3).

Neocamarosporium endophyticum M. Gonçalves \& A. Alves, sp. nov.

Fig. 3

Mycobank: MB829966; Facesoffungi number: FoF06135

Etymology - named for to the endophytic nature of the isolates obtained from plant tissues.

Holotype - MUM-H 18.56

Endophytic in marine habitats. Sexual morph: not observed. Asexual morph: coelomycetous. Conidiomata solitary, pycnidial, immersed to erumpent and globose. Paraphyses absent. Conidia (mean \pm S.D. $=7.8 \pm 1.2 \times 3.2 \pm 0.4 \mu \mathrm{m}, \mathrm{n}=50$ ), solitary, initially hyaline, aseptate, thick-walled, developing a central septum (rarely developing additional septa) when mature with shape variable from obovoid to ellipsoid or subcylindrical, becoming golden-brown.

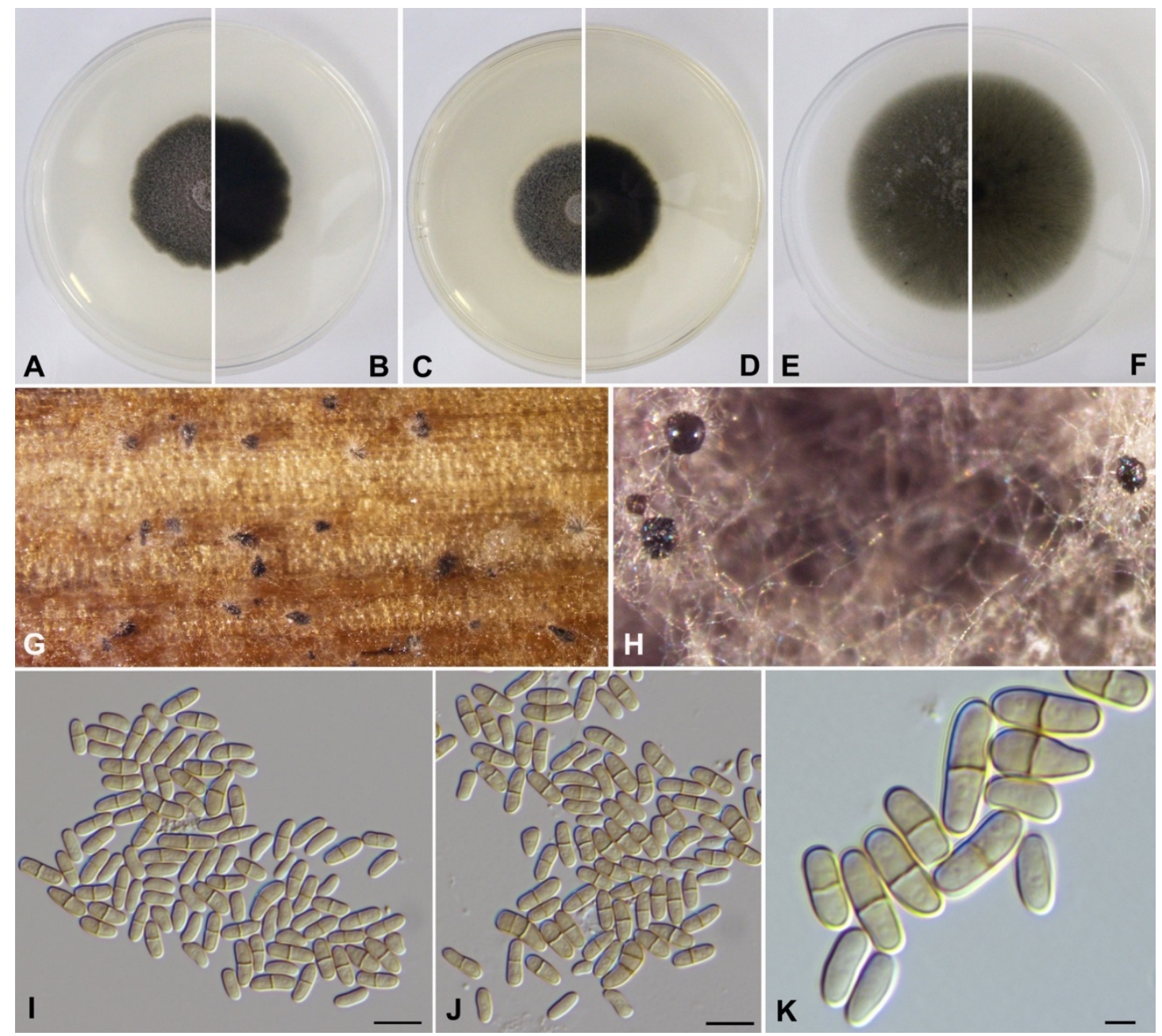

Figure 3 - Neocamarosporium endophyticum (MUM 18.56). a-b Colony after 2 weeks at $25^{\circ} \mathrm{C}$ on PDA (B reverse). c-d Colony after 2 weeks at $25^{\circ} \mathrm{C}$ on MEA (D reverse). e-f Colony after 2 weeks at $25^{\circ} \mathrm{C}$ on OA (F reverse). g Conidiomata developed on fennel stems. h Conidiomata developed on PDA. i-k Conidia. Scale bars: $\mathrm{i}-\mathrm{j}=10 \mu \mathrm{m}, \mathrm{k}=2.5 \mu \mathrm{m}$.

Culture characteristics - Colonies smooth, with fluffy aerial mycelium. On PDA, MEA and OA, olivaceous-grey to olivaceous-black. Colonies growing on PDA and MEA reaching $60 \mathrm{~mm}$ in 14 days at $25{ }^{\circ} \mathrm{C}$, under dark. On OA the colonies grew fast reaching $70 \mathrm{~mm}$ in the same time. At $35^{\circ} \mathrm{C}$, there was only growth in OA with $10 \mathrm{~mm}$ in 14 days. 
Known distribution - Portugal.

Material examined - Portugal, Ria de Aveiro, endophytic isolate from Halimione

portulacoides, October 2017, M. Gonçalves, (MUM-H 18.56 holotype), a dried culture sporulating, ex-holotype living culture MUM 18.56 = CAA808.

Note - Neocamarosporium endophyticum is phylogenetically closely related to $N$. halimiones (MUM 18.54). Although some culture characteristics of both species are similar, they differ in conidial morphology (septate vs. aseptate), dimensions and in 14 nucleotide positions in ITS (Table 2 and 3).

Neocamarosporium halimiones M. Gonçalves \& A. Alves, sp. nov.

Fig. 4

Mycobank: MB829967; Facesoffungi number: FoF06132

Etymology - named for the host it was first isolated from, namely Halimione portulacoides. Holotype - MUM-H 18.54

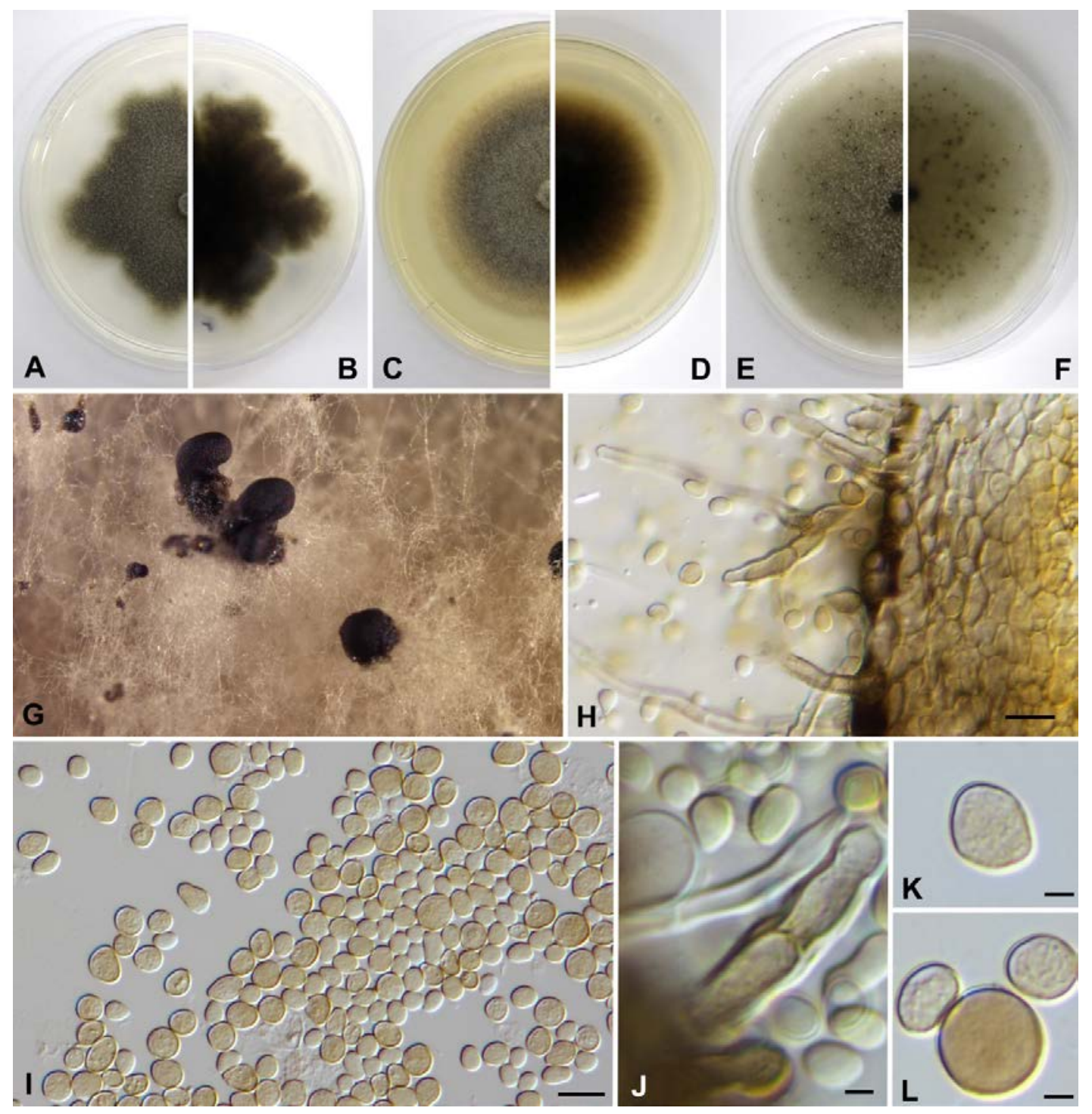

Figure 4 - Neocamarosporium halimiones (MUM 18.54). a-b Colony after 2 weeks at $25{ }^{\circ} \mathrm{C}$ on PDA (B reverse). c-d Colony after 2 weeks at $25^{\circ} \mathrm{C}$ on MEA (D reverse). e-f Colony after 2 weeks at $25{ }^{\circ} \mathrm{C}$ on OA (F reverse). g Conidiomata developed on PDA. h Conidiogenous layer with conidiogenous cells and paraphyses. $\mathrm{j}$ Conidiogenous cells. $\mathrm{i}, \mathrm{k}-\mathrm{l}$ Conidia. Scale bars: $\mathrm{h}-\mathrm{i}=10 \mu \mathrm{m}$, $\mathrm{j}-\mathrm{l}=2.5 \mu \mathrm{m}$.

Endophytic in Halimione portulacoides. Sexual morph: not observed. Asexual morph: coelomycetous. Conidiomata solitary, pycnidial, immersed to erumpent and globose. Paraphyses 
absent. Conidiogenous cells separate, hyaline, smooth, ampulliform. Conidia (mean \pm S.D. $=4.5 \pm$ $0.8 \times 4.0 \pm 0.7 \mu \mathrm{m}, \mathrm{n}=50$ ), solitary, initially hyaline, aseptate, thick-walled, shape variable from globose, subglobose to obovoid or irregular, becoming golden-brown.

Culture characteristics - Colonies smooth, with fluffy aerial mycelium. On PDA surface, margin irregular, olivaceous-grey to olivaceous-black; reverse olivaceous-black. On MEA, olivaceous to olivaceous-grey, margins regular and dirty white. On OA, olivaceous-grey. Colonies growing on PDA and MEA, reaching $50 \mathrm{~mm}$ in 14 days at $25^{\circ} \mathrm{C}$, under dark. On OA the colonies grew faster reaching $65 \mathrm{~mm}$ in the same time. At $35^{\circ} \mathrm{C}$, there was only growth on $\mathrm{OA}$ with $8 \mathrm{~mm}$ in 14 days.

Known distribution - Portugal.

Material examined - Portugal, Ria de Aveiro, endophytic isolate from Halimione portulacoides, October 2017, M. Gonçalves, (MUM-H 18.54 holotype), a dried culture sporulating, ex-holotype living culture MUM 18.54 = CAA 807.

Note - Neocamarosporium halimiones is phylogenetically closely related to $N$. endophyticum (MUM 18.56). They differ mainly in conidial morphology and in 14 nucleotide positions in ITS (Table 2 and 3).

Table 2 Synopsis of recorded Neocamarosporium species discussed in this study.

\begin{tabular}{|c|c|c|c|c|}
\hline Species & $\begin{array}{l}\text { Conidia } \\
\text { Size }(\mu \mathrm{m})\end{array}$ & Septation & Colour & References \\
\hline N. aestuarinum & $10.7 \pm 2.5 \times 12.1 \pm 2.0$ & Muriform & Golden-brown & Present study \\
\hline N. betae & $(2.5-) 4-6.5(-9.5) \times(1.5-) 2.5-4(-5.5)$ & 0 & - & Boerema 1993 \\
\hline N. calvescens & - & 1 & Brown & $\begin{array}{l}\text { Wijayawardene et al. } \\
2016\end{array}$ \\
\hline N. chersinae & $(10-) 12-13(-15) \times(5-) 6(-7)$ & Muriform & Golden-brown & $\begin{array}{l}\text { Crous \& Groenewald } \\
2017\end{array}$ \\
\hline N. chichastianum & $(11-) 15-19(-22) \times(6-) 8-9(-11)$ & Muriform & Brown & Crous et al. 2014b \\
\hline N. endophyticum & $7.8 \pm 1.2 \times 3.2 \pm 0.4$ & $1(-2)$ & Golden-brown & Present study \\
\hline N. goegapense & $(15-) 20-22(-24) \times 15-17(-19)$ & Muriform & Golden-brown & Crous et al. 2014a \\
\hline N. halimiones & $4.5 \pm 0.8 \times 4.0 \pm 0.7$ & 0 & Golden-brown & Present study \\
\hline$N$. jorjanensis & $(9-) 11-12(-13) \times 4-7(-8)$ & Muriform & Golden-brown & Papizadeh et al. 2017 \\
\hline N. korfii & $12-18 \times 8-10$ & Muriform & Dark brown & $\begin{array}{l}\text { Wanasinghe et al. } \\
2017\end{array}$ \\
\hline N. lamiacearum & $14-20 \times 8-11$ & Muriform & Pale brown & $\begin{array}{l}\text { Wanasinghe et al. } \\
2017\end{array}$ \\
\hline$N$. obiones & $8.5-9 \times 3-4$ & 1 & $\begin{array}{l}\text { Pale-yellow to } \\
\text { brownish }\end{array}$ & $\begin{array}{l}\text { Dickinson \& Jones } \\
1966\end{array}$ \\
\hline N. persepolisi & $(8-) 14-18(-19) \times 6-9$ & Muriform & Golden-brown & Papizadeh et al. 2017 \\
\hline N. phragmitis & $12-16 \times 6-8$ & Muriform & Pale brown & Hyde et al. 2018 \\
\hline N. salicorniicola & $8-12 \times 4-6$ & Muriform & Dark brown & $\begin{array}{l}\text { Wanasinghe et al. } \\
2017\end{array}$ \\
\hline N. salsolae & $18-25 \times 12-20$ & Muriform & Dark brown & $\begin{array}{l}\text { Wanasinghe et al. } \\
2017\end{array}$ \\
\hline N. solicola & $(8-) 12(-16) \times(2-) 2.5(-4)$ & 0 & Hyaline & Papizadeh et al. 2017 \\
\hline
\end{tabular}

Table 3 Major ITS base pair differences of Neocamarosporium aestuarinum, $N$. chersinae, $N$. chichastianum, $N$. endophyticum, $N$. halimiones and $N$. jorjanensis. n.b. nonexistent base.

\begin{tabular}{lll}
\hline Species & Base pair difference & Place of ITS nucleotides difference \\
\hline & G instead of A & 36,481 \\
& A instead of n.b. & $41,180,401$ \\
N. aestuarinum and $N$. jorjanensis & C instead of T & 42,70, \\
& T instead of C & 48,395 \\
& A instead of G & $132,402,487$ \\
\hline
\end{tabular}


Table 3 Continued.

\begin{tabular}{|c|c|c|}
\hline Species & Base pair difference & Place of ITS nucleotides difference \\
\hline & T instead of n.b. & $96-400$ \\
\hline & n.b. instead of $A$ & 422 \\
\hline & C instead of A & 435 \\
\hline & n.b. instead of C & 475,496 \\
\hline & n.b. instead of $\mathrm{T}$ & 482 \\
\hline \multirow{7}{*}{ N. endophyticum and $N$. halimiones } & A instead of $\mathrm{T}$ & 26 \\
\hline & T instead of C & $33,42,44,50,378$ \\
\hline & C instead of $\mathrm{T}$ & $40,347,372$ \\
\hline & A instead of G & 52 \\
\hline & G instead of A & 113 \\
\hline & C instead of n.b. & 474 \\
\hline & T instead of n.b. & 475,462 \\
\hline \multirow{10}{*}{ N. endophyticum and N. chichastianum } & A instead of $G$ & $13,19,52$ \\
\hline & A instead of $\mathrm{T}$ & 26,68 \\
\hline & C instead of $\mathrm{T}$ & 32, 347, 372, 393, 447 \\
\hline & T instead of C & $33,50,66,378$ \\
\hline & G instead of A & 113 \\
\hline & C instead of n.b. & 374 \\
\hline & T instead of n.b. & 375,462 \\
\hline & C instead of G & 386 \\
\hline & G instead of C & 389 \\
\hline & T instead of $\mathrm{G}$ & 448 \\
\hline \multirow{10}{*}{$N$. endophyticum and $N$. chersinae } & G instead of $A$ & $7,21,113$ \\
\hline & A instead of $G$ & 19,25 \\
\hline & A instead of C & 22 \\
\hline & A instead of $\mathrm{T}$ & 26 \\
\hline & $\mathrm{C}$ instead of $\mathrm{T}$ & 32, 347, 372 \\
\hline & T instead of C & $33,50,140,378$ \\
\hline & G instead of $\mathrm{T}$ & 39 \\
\hline & C instead of n.b. & 374 \\
\hline & T instead of n.b. & 375,462 \\
\hline & $\mathrm{T}$ instead of $\mathrm{G}$ & 448 \\
\hline \multirow{8}{*}{$N$. halimiones and $N$. chichastianum } & A instead of $G$ & 12,18 \\
\hline & $\mathrm{C}$ instead of $\mathrm{T}$ & 31 \\
\hline & T instead of C & $39,65,390$ \\
\hline & $\mathrm{C}$ instead of $\mathrm{T}$ & $41,43,444$ \\
\hline & A instead of $\mathrm{T}$ & 77 \\
\hline & C instead of G & 383 \\
\hline & G instead of C & 386 \\
\hline & T instead of $G$ & 445 \\
\hline \multirow{8}{*}{$N$. halimiones and $N$. chersinae } & G instead of $A$ & $6,20,51$ \\
\hline & A instead of G & 8,24 \\
\hline & A instead of C & 21 \\
\hline & C instead of $\mathrm{T}$ & 31 \\
\hline & G instead of $T$ & 38 \\
\hline & $\mathrm{T}$ instead of $\mathrm{C}$ & 39, 139 \\
\hline & $\mathrm{C}$ instead of $\mathrm{T}$ & 41,43 \\
\hline & T instead of G & 445 \\
\hline
\end{tabular}

\section{Discussion}

The genus Neocamarosporium harbours 15 species described so far (Index Fungorum 2019). This study adds three novel species isolated from saline environments, namely Neocamarosporium aestuarinum, $N$. endophyticum and $N$. halimiones. The introduction of these species is well supported by morphological and phylogenetic data. 
Crous et al. (2014a) introduced Neocamarosporium as a new genus distinct from Camarosporium. The presence of two distinct groups within Neocamarosporium with morphological and phylogenetic differences based on combined dataset of ITS and $\beta$-tubulin was reported by Papizadeh et al. (2017) suggesting the possibility of these representing two separate genera. One clade comprises the species $N$. betae, $N$. calvescens and $N$. solicola which have hyaline aseptate conidia and a second clade contains $N$. goegapense, $N$. jorjanensis, $N$. chichastianum and $N$. persepolisi with muriformly septate brown conidia. However, there was no $\beta$-tubulin sequence data available for most species and therefore the phylogenetic analysis presented did not encompass all known species in Neocamarosporium.

The three novel species described in this study are supported by morphological as well as DNA base pair differences as outlined by Jeewon \& Hyde (2016). In our phylogenetic analysis, $N$. aestuarinum is more closely related to $N$. jorjanensis with high bootstrap support. Comparison of the ITS sequence from $N$. aestuarinum and $N$. jorjanensis revealed 23 base pair differences which support the establishment of $N$. aestuarinum as a distinct species. Neocamarosporium aestuarinum and $N$. jorjanensis have similar golden-brown and muriform conidia but can be differentiated by the size of conidia.

Neocamarosporium endophyticum and $N$. halimiones cluster together but their ITS sequences have 14 base pair differences. In addition, a comparison of the ITS sequences of $N$. endophyticum and other closely related Neocamarosporium species such as $N$. chersinae and $N$. chichastianum revealed 19 and 21 base pair differences, respectively. Same comparison with $N$. halimiones revealed 13 base pair differences with both $N$. chersinae and $N$. chichastianum. Morphologically, $N$. endophyticum and $N$. halimiones can be easily discriminated. The conidia of $N$. halimiones are aseptate, initially hyaline and soon become golden-brown while conidia of $N$. endophyticum are golden-brown and have a single central septum.

Two of the species described here, namely $N$. halimiones and $N$. aestuarinum, challenge the separation of the genus into two groups based on conidial characters as suggested by Papizadeh et al. (2017). Despite this, it is evident that the genus Neocamarosporium as currently circumscribed encompasses a wide diversity of conidial morphologies. It is possible that these different morphologies correspond to different genera. For example, Wijayawardene et al. (2014) established two genera, Pseudocamarosporium and Paracamarosporium. Although phylogenetically very close and have both pycnidial conidiomata, enteroblastic and phialidic conidiogenesis with percurrent proliferation and muriform conidia, they differ in microconidia morphology. However, multi-gene phylogenies including all Neocamarosporium species are needed to evaluate if these morphological groups represent distinct genera or not.

The majority of the Neocamarosporium species described so far appear to have some host and habitat preference, i.e. ecologically they can be found in estuarine or marine habitats in association with various genera of halophytes, such as, Atriplex, Beta, Chenopodium, Halimione, Mesembryanthemum, Phragmites, Salicornia and Salsola (Crous et al. 2014b, Ariyawansa et al. 2015, Wanasinghe et al. 2017). Papizadeh et al. (2017) reported the presence of Neocamarosporium species in hypersaline lakes soils in Iran, showing their halotolerance capacity by the ability to grow in media containing various concentrations of $\mathrm{NaCl}$ and $\mathrm{MgCl}_{2}$. In fact, halotolerance seems to be a typical characteristic of the genus as suggested by Papizadeh et al. (2017). The species described here can be regarded as halotolerant as they grow equally well in the presence and absence of sea salts.

It is noteworthy that saline environments encompass such a high diversity of Neocamarosporium species and further studies will be necessary to understand the ecological role of these species in estuarine, marine and other saline habitats. Species of Neocamarosporium are regarded as pathogenic or saprobic on dying leaves and stems (Ariyawansa et al. 2015, Wanasinghe et al. 2017). However, their status as pathogens needs to be properly addressed as no clear evidence of their pathogenicity has been shown so far.

Here we describe three novel species that occur as endophytes on healthy tissues (leaves and stems) of the halophyte $H$. portulacoides, being $N$. aestuarinum also found in sea water and $N$. 
endophyticum on dead leaves of Z. noltii. With four distinct species described so far ( $N$. aestuarinum, $N$. endophyticum, $N$. halimiones and $N$. obiones), the salt-tolerant $H$. portulacoides seems to represent a diversity hotspot of the genus Neocamarosporium that deserves further investigation.

The relevance of the endophytic species reported for the host (H. portulacoides) harbouring them is unknown. However, as reported for other endophytes it is possible that these species have some plant-growth promoting effects thus contributing to the overall plant health and performance. Also, these species may have a significant contribution to the halophytes ability to tolerate salt stress as well as other environmental stresses (Sun et al. 2011, Ruppel et al. 2013). Future research should be conducted in order to better understand these Neocamarosporium-halophytes and their functional interactions.

\section{Acknowledgements}

The authors acknowledge the financial support from Fundação para a Ciência e a Tecnologia (FCT) to CESAM (UID/AMB/50017/2019) and the PhD grant of $\mathrm{M}$. Gonçalves (SFRH/BD/129020/2017).

\section{References}

Alves A, Correia A, Luque J, Phillips AJL. 2004 - Botryosphaeria corticola sp. nov. on Quercus species, with notes and description of Botryosphaeria stevensii and its anamorph Diplodia mutila. Mycologia 96, 598-613.

Azevedo E, Caeiro MF, Rebelo R, Barata M. 2011 - Biodiversity and characterization of marine mycota from Portuguese waters. Animal Biodiversity and Conservation 34, 205-215.

Ariyawansa HA, Thambugala KM, Manamgoda DS, Jayawardena R et al. 2015 - Towards a natural classification and backbone tree for Pleosporaceae. Fungal Diversity 71, 85-139.

Ariyawansa HA, Phillips AJ, Chuang WY, Tsai I - 2018. Tzeananiaceae, a new pleosporalean family associated with Ophiocordycepsmacroacicularis fruiting bodies in Taiwan. MycoKeys 37, 1-17.

Boerema GH. 1993 - Contributions towards a monograph of Phoma (Coelomycetes) - II. Section peyronellaea. Persoonia-Molecular Phylogeny and Evolution of Fungi 15, 197-221.

Butinar L, Santos S, Spencer-Martins I, Oren A et al. 2005a - Yeast diversity in hypersaline habitats. FEMS Microbiology Letters 244, 229-234.

Butinar L, Sonjak S, Zalar P, Plemenitaš A et al. 2005b - Melanized halophilic fungi are eukaryotic members of microbial communities in hypersaline waters of solar salterns. Botanica Marina 48, 73-79.

Crous PW, Shivas RG, Quaedvlieg W, van der Bank M et al. 2014a - Fungal Planet description sheets: 214-280. Persoonia 32, 184-306.

Crous PW, Wingfield MJ, Schumacher RK, Summerell BA et al. 2014b - Fungal Planet description sheets: 281-319. Persoonia 33, 212-289.

Crous PW, Wingfield MJ, Guarro J, Hernández-Restrepo M et al. 2015 - Fungal Planet description sheets: 320-370. Persoonia 34, 167-266.

de Gruyter JC, Woudenberg JHC, Aveskamp MM, Verkley GJM et al. 2013 - Redisposition of phoma-like anamorphs in Pleosporales. Studies in Mycology 75, 1-36.

Devadatha B, Sarma VV, Jeewon R, Wanasinghe DN et al. 2018a - Thyridariella, a novel marine fungal genus from India: morphological characterization and phylogeny inferred from multigene DNA sequence analyses. Mycological progress 17, 791-804.

Devadatha B, Sarma VV, Jeewon R, Jones EG. 2018b - Morosphaeria muthupetensis sp. nov. (Morosphaeriaceae) from India: morphological characterization and multigene phylogenetic inference. Botanica marina 61, 395-405. 
Dickinson CH, Morgan-Jones G. 1966 - The mycoflora associated with Halimione portulacoides. IV. Observations on some species of Sphaeropsidales. Transactions of the British Mycological Society 49, 43-55.

Gunde-Cimerman N, Zalar P, Petrovič U, Turk M et al. 2004 - Fungi in the salterns. In: Ventosa A (ed) Halophilic microorganisms. Springer, Berlin, Heidelberg.

Hall TA. 1999 - BioEdit: a user-friendly biological sequence alignment editor and analysis program for Windows 95/98/NT. Nucleic Acids Symposium Series 41, 95-98.

Hyde KD, Jones EBG. 1998 - Marine mangrove fungi. Marine Ecology 9, 15-33.

Hyde KD, Pointing SB. 2000 - Marine mycology: a practical approach. Fungal Diversity Press, Hong Kong.

Hyde KD, Chaiwan N, Norphanphoun C, Boonmee S et al. 2018 - Mycosphere notes 169-224. Mycosphere, 9, 271-430.

Jeewon R, Hyde KD. 2016 - Establishing species boundaries and new taxa among fungi: recommendations to resolve taxonomic ambiguities. Mycosphere 7, 1669-1677.

Jones EBG, Suetrong S, Sakayaroj J, Bahkali AH et al. 2015 - Classification of marine Ascomycota, Basidiomycota, Blastocladiomycota and Chytridiomycota. Fungal Diversity 73, $1-72$.

Kis-Papo T, Grishkan I, Oren A, Wasser SP et al. 2001 - Spatiotemporal diversity of filamentous fungi in the hypersaline Dead Sea. Mycology Research 105, 749-756.

Kis-Papo T, Oren A, Wasser SP, Nevo E. 2003 - Survival of filamentous fungi in hypersaline Dead Sea water. Microbial Ecology 45, 183-190.

Kumar S, Stecher G, Tamura K. 2016 - MEGA7: Molecular Evolutionary Genetics Analysis version 7.0 for bigger datasets. Molecular Biology and Evolution 33, 1870-1874.

Möller EM, Bahnweg G, Sandermann H, Geiger HH. 1992 - A simple and efficient protocol for isolation of high molecular weight DNA from filamentous fungi, fruit bodies, and infected plant tissues. Nucleic Acids Research 20, 6115-6116.

Papizadeh M, Wijayawardene NN, Amoozegar MA, Saba F et al. 2017 - Neocamarosporium jorjanensis, N. persepolisi and N. solicola spp. nov. (Neocamarosporiaceae, Pleosporales) isolated from saline lakes of Iran indicate the possible halotolerant nature for the genus. Mycological Progress 17, 661-679.

Poon MOK, Hyde KD. 1998 - Biodiversity of intertidal estuarine fungi on Phragmites at Mai Po marshes, Hong Kong. Botanica Marina 41, 141-155.

Rayner RW. 1970 - A Mycological Colour Chart. Kew: Commonwealth Mycological Institute.

Ruppel S, Franken P, Witzel K. 2013 - Properties of the halophyte microbiome and their implications for plant salt tolerance. Functional Plant Biology 40, 940-951.

Sarma VV, Hyde KD. 2001 - A review on frequently occurring fungi in mangroves. Fungal Diversity 8, 1-34.

Sun Y, Wang Q, Lu XD, Okane I et al. 2011 - Endophytic fungi associated with two Suaeda species growing in alkaline soil in China. Mycosphere 2, 239-248.

Tanaka K, Hirayama K, Yonezawa H, Sato G et al. 2015 - Revision of the Massarineae (Pleosporales, Dothideomycetes). Studies in Mycology 82, 75-136.

Thompson JD, Gibson TJ, Plewniak F, Jeanmougin F et al. 1997 - The CLUSTAL_X windows interface: flexible strategies for multiple sequence alignment aided by quality analysis tools. Nucleic Acids Research 25, 4876-4882.

Wanasinghe DN, Hyde KD, Jeewon R, Crous PW et al. 2017 - Phylogenetic revision of Camarosporium (Pleosporineae, Dothideomycetes) and allied genera. Studies in Mycology 87, 207-256.

White TJ, Bruns T, Lee S, Taylor J. 1990 - Amplification and direct sequencing of fungal genes for phylogenies. In: Innis MA, Gelfand DH, Sninsky JJ, White TJ (eds), PCR Protocols: A guide to methods and applications. Academic Press, California, pp. 315e322. 
Wijayawardene NN, Crous PW, Kirk PM, Hawksworth DL et al. 2014 - Naming and outline of dothideomycetes - 2014 including proposals for the protection or suppression of generic names. Fungal Diversity 69, 1-55.

Wijayawardene NN, Hyde KD, Bhat DJ, Goonasekara ID et al. 2015 - Additions to brown spored coelomycetous taxa in Massarinae, Pleosporales: introducing Phragmocamarosporium gen. nov. and Suttonomyces gen. nov. Cryptogamie Mycologie 36, 213-225.

Wijayawardene NN, Hyde KD, Wanasinghe DN, Papizadeh M et al. 2016 - Taxonomy and phylogeny of dematiaceous coelomycetes. Fungal Diversity 77, 1-316.

Wijayawardene NN, Papizadeh M, Phillips AJL, Wanasinghe DN et al. 2017a - Mycosphere Essays 19: recent advances and future challenges in taxonomy of coelomycetous fungi. Mycosphere 8, 934-950.

Wijayawardene NN, Hyde KD, Rajeshkumar KC, Hawksworth DL et al. 2017b - Notes for genera: Ascomycota. Fungal Diversity 86, 1-594. 